DOI: 10.20472/BMC.2018.008.004

\author{
IRMA GUGA \\ UNIVERSITY OF TIRANA, Albania
}

\title{
ECONOMIC FREEDOM IN ALBANIA
}

\begin{abstract}
:
At early stages of transition, markets are in their first steps and sometimes do not exist in the literal sense of the word. Even after many years of development, the markets in transitional economies may be imperfect as well as incomplete. In these circumstances we cannot pretend the market system itself will determine prices and reallocate resources to more productive sectors.
\end{abstract}

Also, being for many decades isolated from the outside world and external development, the economy and enterprises themselves are in great need of new and advanced technology. Obviously, there is need of economic sustainability and the social environment for the establishment and development of private sector.

In these circumstances, obviously there is need for some restrictions and obligations. These are necessary for the very existence of a country, but when these limits exceed the target then the problem arises. Economic freedom, inter alia, will be defined as "the lack of pressure or governmental constraints on the production, distribution or consumption of utility goods beyond what is needed for citizens to protect and preserve their freedom to work, produce, consume and invested so that they feel they are productive "(Angjeli, A; 2007: 70).

Over two-thirds of studies on economic freedom, found it to correspond to a "good" outcome such as faster growth, better living standards, more happiness, etc. ( Hall, C. J; Lawson, A. R; 2013)

For these reasons, we are having a look on economic freedom to see how this indicator has affected the Albanian economy and whether its values are comparable to those of the countries we aspire to.

\section{Keywords:}

economic freedom, economy growth, rule of law, government size, regulatory efficiency, open markets

JEL Classification: $010, \mathrm{H} 10, \mathrm{P} 14$ 


\section{A view on Economic Freedom Index}

A primary purpose for the creation of the EFW index was to inject some much needed scientific fact into the ongoing debate about the merits of free-market economic systems versus interventionist systems. What had characterized this debate for most of its history was a paucity of data and evidence. With the creation of the EFW index we may begin to address the problem of economic organization as scientists should by measurement of reality and testing of various hypotheses (Lawson, Robert A. 2006: 3)

Economic freedom is one of the key elements in the market economy, while it can be said that all the challenges for developing countries is the achievement of this economic freedom. The "father" of market economy Adam Smith in his book "The Wealth of Nations" in 1776 emphasizes that, institutions that protect individuals' freedom to pursue their economic interests, work best in great societies.

Also, the importance of measuring economic freedom for a country is not related simply to the definition of extremes of anarchy and utopia, but the description of the country's economy as it is. (Angjeli, A; 2007: 71)

According to The Heritage Foundation the index of Economic Freedom documents the positive relationship between economic freedom and a variety of positive social and economic goals.

The Economic Freedom of the World (EFW) index was first produced by Gwartney, Block, and Lawson (Economic Freedom of the World: 1975-1995; 1996) and has been updated annually since then.

This indicator summarizes all the economic and financial indicators of a country. In other terms, it is the twist of all economic variables that analyze the interaction of freedom with the "health of the economy". Since 1995, Economic Freedom Index is studied from the famous "The Heritage Foundation/Wall Street Journal/ Index of Economic Freedom for 186 states and is organised in four pillars, compoused by 12 variables as follows:

I. Rule of Law

Judicial effectiveness

Property rights

Government integrity
II. Government size

Tax burden

Government spending

Fiscal health 
III. Regulatory efficiency

Business freedom

Labor freedom

Monetary freedom
IV. Open markets

Trade freedom

Investment freedom

Financial freedom

All these freedoms create a favorable environment for entrepreneurship, innovation, sustainable economic growth and economic development. As a result, what will accompany the latter is a higher GDP per capita for all residents of that country.

A higher point of an indicator means less intervention of the government in the economy. Thus, the greater the country's economic freedom indicator, the greater the GDP per capita, and further on as a cyclical process, this per capita GDP will lead to further improvements in the figures of economic freedom.

The greater the number of obstacles and the economic constraints of a country, the less likely to be realized, the efforts of these individuals and the improvement of their wellbeing are made (Angjeli, A; 2007: 67).

These constraints and obstacles are made by the government with its incentive or repressive policies. There is a very important issue about the desirable role of government in developing countries. This would be even more or less a regulatory role that would ensure the guarantee and enforcement of laws, the securing of copyright and many other freedoms, thus guaranteeing the macroeconomic stability of a country. A very important aspect is the role of the government in the fight against corruption and unfair competition.

While it is by now clear that achieving economic growth and prosperity depends on the complex interaction of many factors-policy, culture, geography, legal origins-perhaps even a fair amount of luck, development economists increasingly refer to institutions as one of the most important and "deep" determinants for sustained economic prosperity (Acemoglu et al., 2005a, 2005b; Economides and Egger, 2009). Some economists even suggest that institutions are now at the forefront of mainstream economic theory (Jones and Romer, 2009). Institutions play a vital role in reducing transaction costs and shaping the appropriate incentives that drive long-run economic growth and development. 


\section{Economic Freedom in Albania}

Albania's economic freedom score is 64.5, making its economy the 65th freest in the 2018 Index. Meanwhile, it is ranked 32nd among 44 countries in the Europe region (Economic Freedom Index, 2018/Albania). If we see the data of Regional ranking we may look that Albania is behind countries as Poland, Hungary, Belgium, Turkey etc. Meanwhile, it is above countries of European Union as Italy, France, Portugal and Balkan countries as Montenegro, Serbia and Bosnia \& Hercegovina (Anex. 1, Table 1).

The 65th place in world rankings is "translated" for Albania as a "Moderately Free" country (Figure 1). In 2018, the country is ranked side by side with other European Union countries such as France, Italy, Spain, Hungary etc. At the same time, the countries of the region rank in these values, except Macedonia, which is ranked as a "Mostly Free" country.

According to Economic Freedom Index 2018, its overall score has increased by 0.1 point, with a dramatic improvement in fiscal health offsetting lower scores for the judicial effectiveness and tax burden indicators and a sharp decline in business freedom.

If we look at the data (Figure 2), we will point out that the Economic Freedom Index (overall score), with some exception, has risen from year to year. In 2006, Albania has reached the level of the World Index, and since that year has been at higher levels compared to it, but lower than the level of this index for the European countries. 


\section{Figure 1: Economic Freedom Scores in Europe}

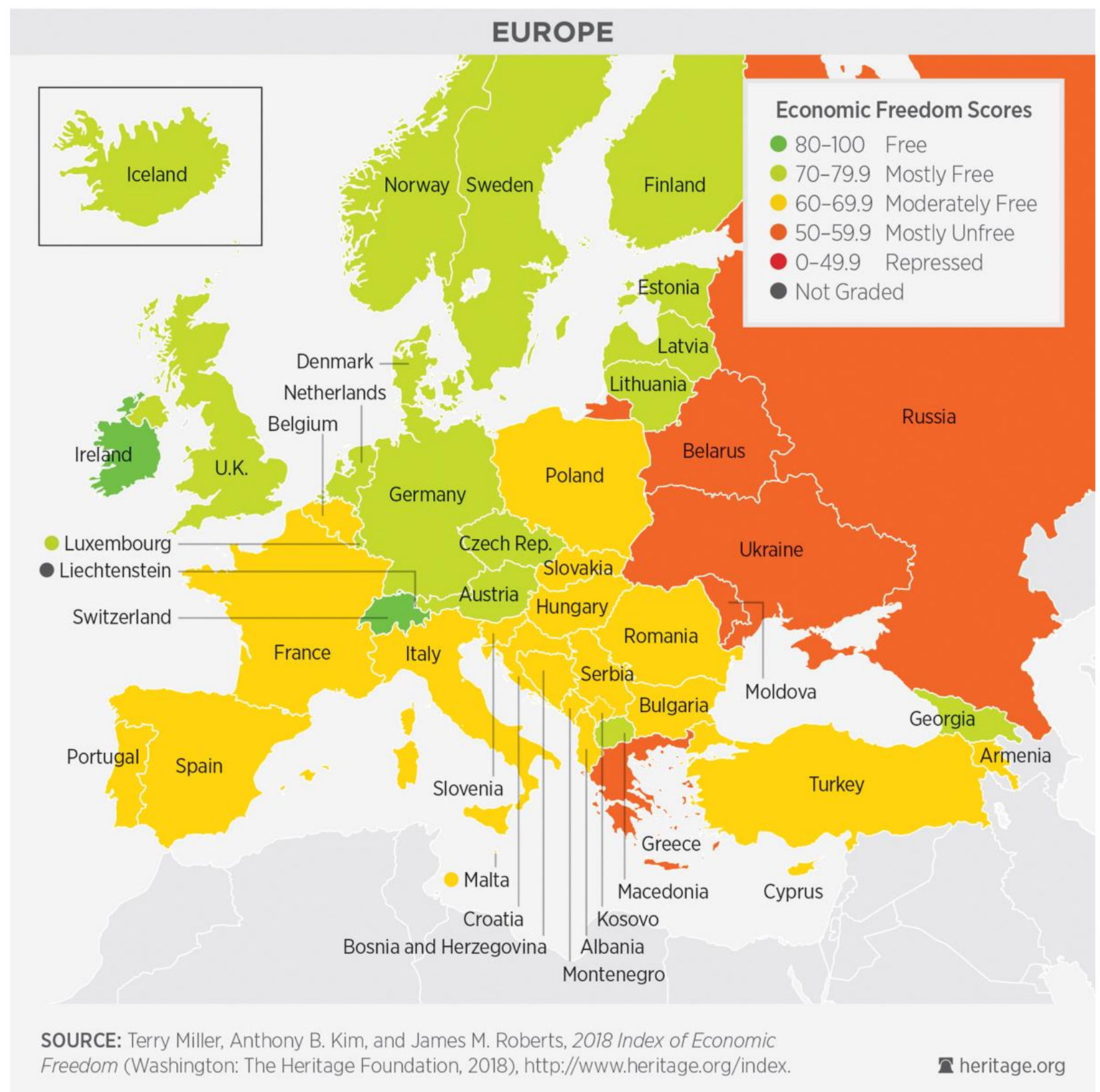

This index has reached the highest levels in 2010 with $66 \%$, ranking Albania $66^{\text {th }}$ and then in 2014 with $66.9 \%$ by ranking the country $67^{\text {th }}$.

These levels of this indicator are not a coincidence. This is explained by the achievements and progress made in Albania throughout all this period in terms of trade liberalization (Membership in WTO, about 28 Regional Free Trade Agreements in SEE countries, Stabilization and Association Agreement with EU on 2006, etc.), reduction of 
fiscal barriers, prudent and neutral monetary policy followed by Central Bank of Albania, financial freedom (total privatization of state banks and new private banks), allowing the privatization and total liberalization of economic system.

\section{Figure 2: Albania, Overall score through years}

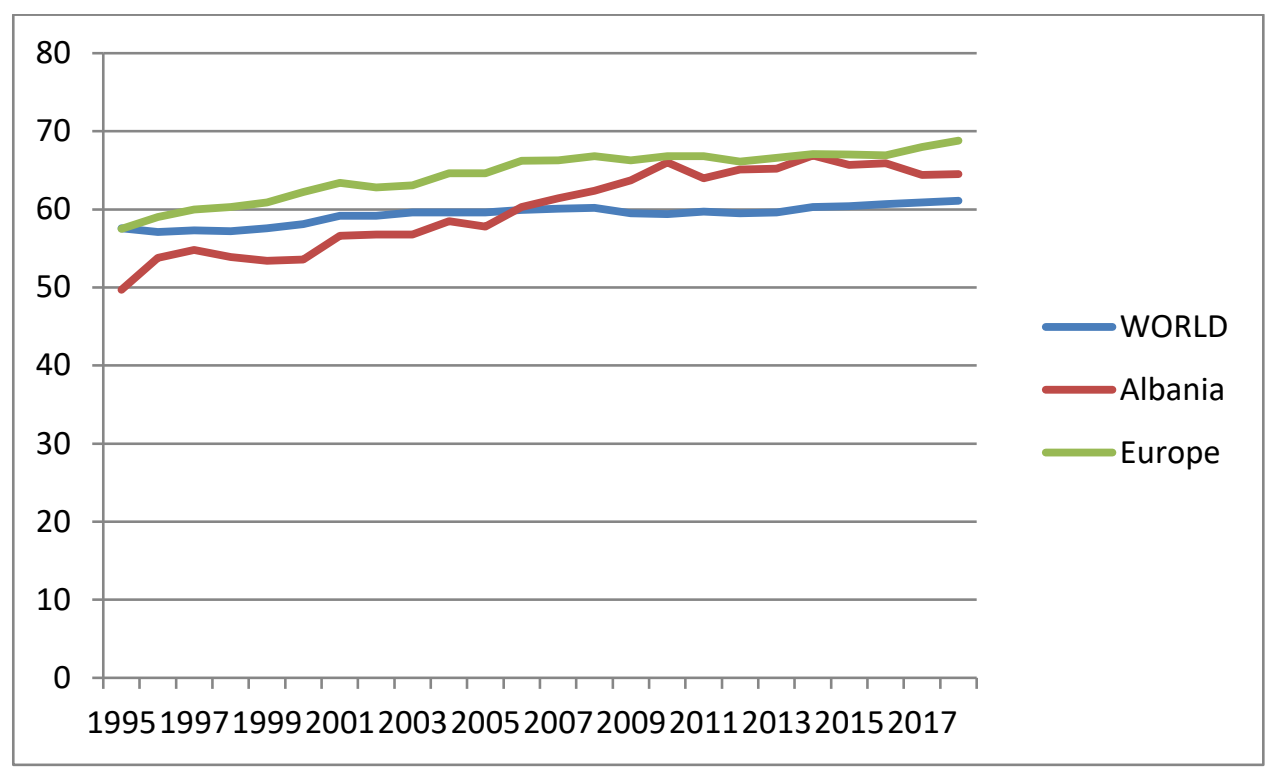

Source: Index of Economic Freedom

But as we mentioned before, despite the encouraging data, what is noticed on 2018 (but not only) are lower scores for the judicial effectiveness and tax burden indicators and a sharp decline in business freedom $(79.3 \%$ in 2017 by reaching the free level and $69.1 \%$ in 2018 by turning back in moderately free levels) (Economic Freedom Index, 2018/Albania).

Also, the observed data during years shows lower levels of "Rule of law" components and precisely Property Rights, Judicial Effectiveness, Government Integrity.

By taking into account that each freedom is weighted equally in determining country scores, there is much to do regarding this pillar (Rule of Law). Protection of property rights is still being reestablished after the long Communist era. Clear titles to property are difficult to obtain. Endemic corruption, most apparent in the judiciary, seriously limits government accountability. The constitutionally independent judiciary is subject to political pressure, intimidation, and limited resources. (Economic Freedom Index, 2018/Albania).

One of the most important criteria for Albania to join the European Union is implementing judicial reforms required by the EU. 
Let us take a look to these three components:

\section{Property Rights}

During 1995-1997, this index has been on the levels of $50 \% \mathrm{i}$, while followed by a sharp decline in 1997-1998 at 30\%, a period corresponding to the 1997 crisis in the country. After this year until 2009 this index has been stable and to be followed by some fluctuations in the years to come. After 2017, this index for Albania has come out of the "danger zone" and reached the level "mostly unfree" (50\%-60\%).

Regarding "Property Rights" Albania has higher points than Bosnia and Hercegovina (during all the period of 1995-2018). Meanwhile for the last two years has an also higher point than Serbia (50.3\% and 46.2\% respectively in 2017 and 2018) and lower than Croatia (65.5\% and 65.95 respectively in 2017 and 2018) and Macedonia (67\% and $64.8 \%$ respectively in 2017 and 2018 ).

\section{Figure 3: Property Rights index}

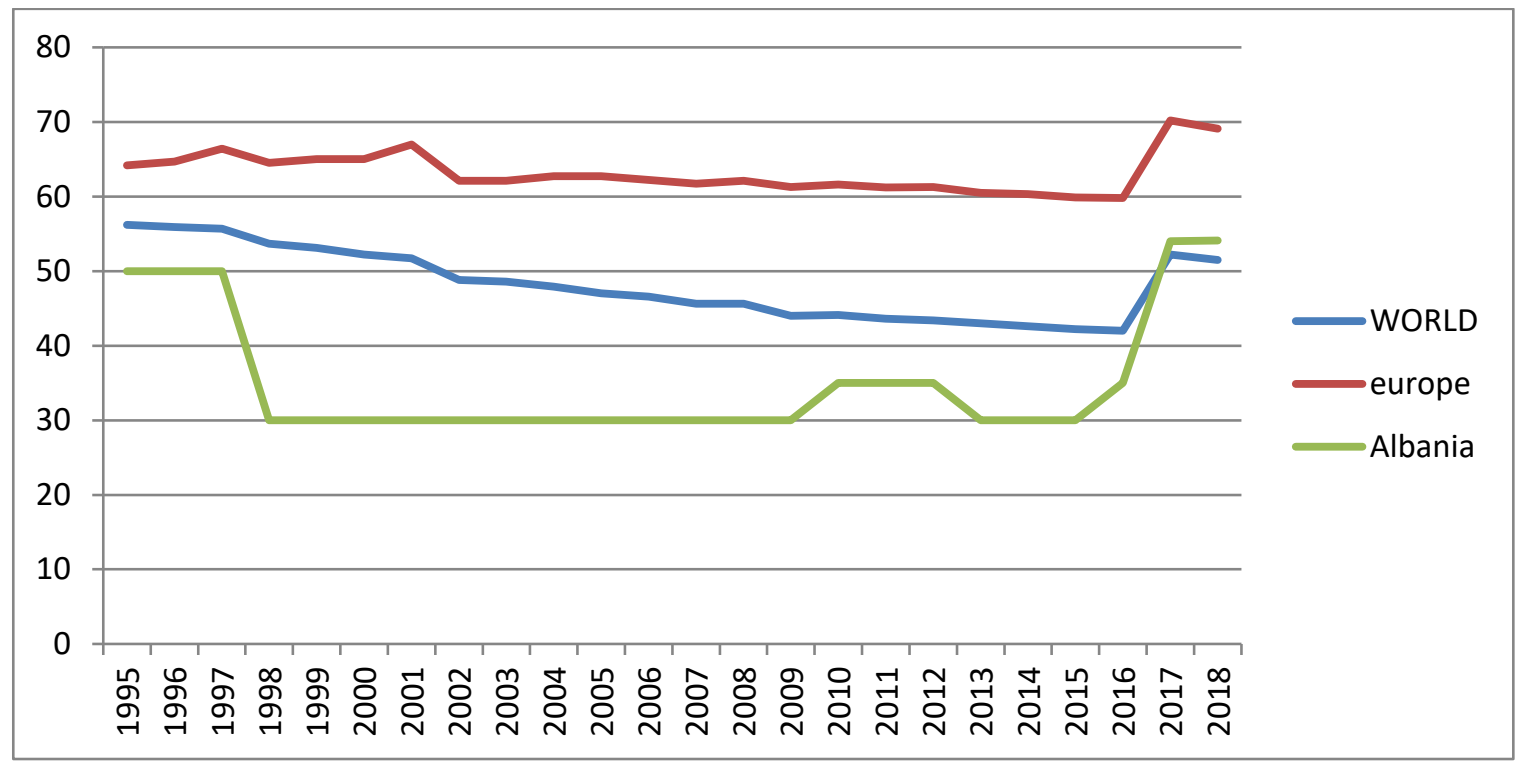

Source: Index of Economic Freedom

i: Values lower than $50 \%$ shows a repressed freedom of property rights; $50 \%-60 \%$ mostly unfree; $60 \%-70 \%$ moderately free; $70-80 \%$ mostly free and values over $80 \%$ free. 


\section{Government Integrity}

As we may see from Figure 4, this index has been characterized by a continued growth after 2000. But, anywhere the data are in undesirable levels. Only on 2018 the levels reached $40 \%$ ii, by staying anyway on "danger zone", the repressed one.

Regarding Government Integrity, Albanian values are comparable with some of Regional countries such as Croatia (43.4\% and 40.5\% respectively in 2017 and 2018), Serbia (38.2\% and 36.5\% respectively in 2017 and 2018). Meanwhile, Macedonia has higher levels $(50.2 \%$ and $47.4 \%$ respectively in 2017 and 2018) and Bosnia and Hercegovina lower levels (32.7\% and $28.4 \%$ respectively in 2017 and 2018$)$.

\section{Figure 4: Government Integrity Index}

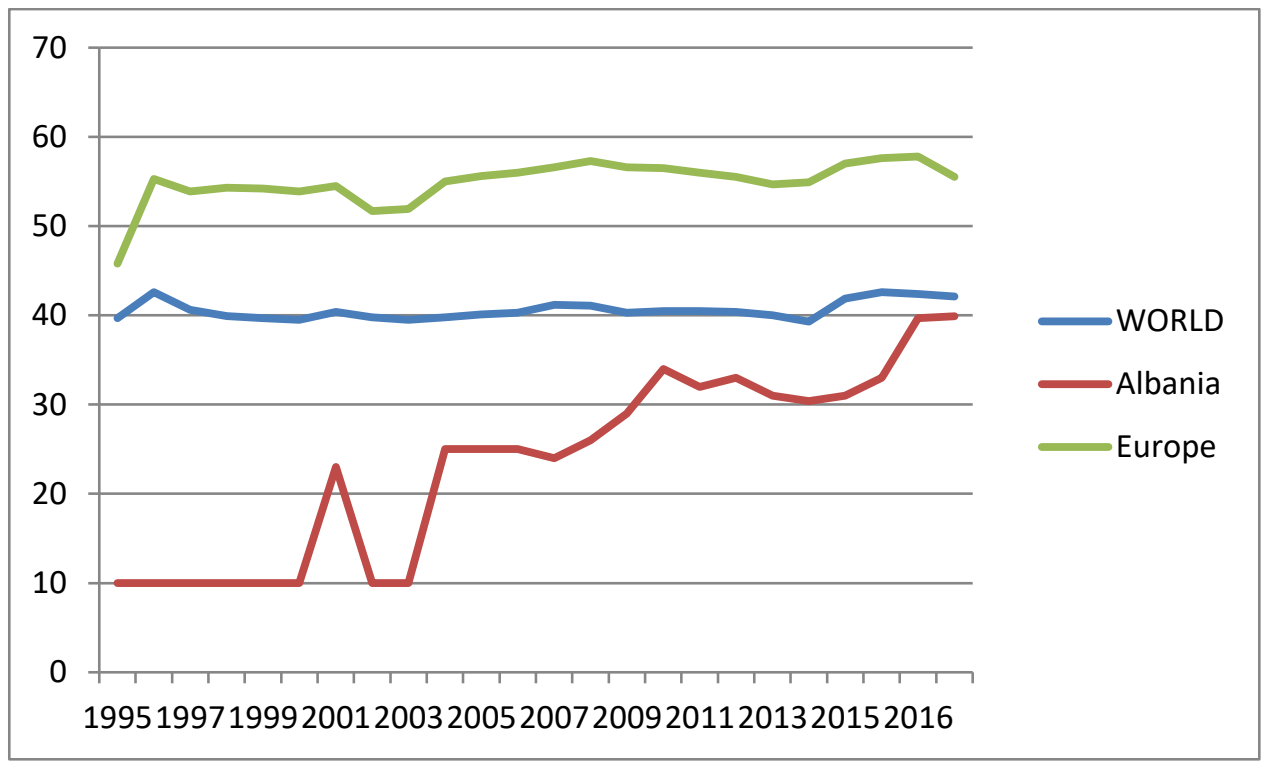

Source: Index of Economic Freedom

Judicial Effectiveness

"Judicial Effectiveness" data for all the countries are provided by Economic Freedom Index only for 2017 and 2018.

ii Values less than $40 \%$ shows a repressed freedom of government integrity 
From the below data we may see that this index in Albania is in very low levels, by categorizing Judicial Effectiveness as a "repressed freedom of judicial effectiveness" (with a decrease from 2017 to 2018).

Figure 4: Judicial Effectiveness

$\begin{array}{lrr}\text { Country } & \mathbf{2 0 1 7} & \mathbf{2 0 1 8} \\ \text { Albania } & 28.5 & 25.4 \\ \text { WORLD } & 44.4 & 46.9 \\ \text { Europe } & 60.2 & 62.3\end{array}$

Source: Index of Economic Freedom

Regarding "Judicial Effectiveness" Albania is far away even from Regional countries as Bosnia and Hercegovina (40\%; 43.7\% respectively for 2017 and 2018), Serbia (40.2\% and $48.2 \%$ ) etc. Meanwhile Macedonia (Northern Macedonia) is ranking between moderately free-Mostly free.

\section{Conclusions}

Albania's transition to a more open and flexible economic system has been facilitated by a decade of substantial restructuring. Progress in income growth and poverty reduction has been considerable. A competitive trade regime supported by a relatively efficient regulatory framework has encouraged the development of a growing entrepreneurial sector. (The Heritage Foundation).

Trade is a very important issue for Albania. Progress has been made in open markets incentives. Government openness to foreign investment is above average, ranking Albania as one of the largest recipients of FDI flows in the subregion. The financial system remains relatively well developed and stable. The banking sector is well provisioned, but the share of nonperforming loans has been rising.

Also, progress has been made in regulatory efficiency, according monetary and bussiness freedom, but there is still a lot to do to reduce informal employment.

Despite this progress, however, more reforms are needed, especially in the area of rule of law. Further reforms are needed in property rights, reduction of corruption and informality in order to reach the desirable levels and to make Albania more attractive for all foreign and domestic investors. 
Reform in Justice system accompanied by concrete measures (vetting in the justice system, approval of the Law No. 95/2016, on "The organization and functioning of institutions for fight corruption and organized crime", establishment of National Bureau of Investigation, Special Structure against corruption and organized crime etc.) is the theme of the day in the country, thus constituting a very encouraging element for Albania's socio-political and economic development.

\section{Anex 1}

Table 1: Regional Ranking

\begin{tabular}{|c|l|c|c|}
\hline Rank & Country & Overall & Change \\
\hline $\mathbf{2 0}$ & $\underline{\text { Armenia }}$ & 68.7 & -1.6 \\
\hline $\mathbf{2 1}$ & $\underline{\text { Poland }}$ & 68.5 & 0.2 \\
\hline $\mathbf{2 2}$ & Malta & 68.5 & 0.8 \\
\hline $\mathbf{2 3}$ & $\underline{\text { Bulgaria }}$ & 68.3 & 0.4 \\
\hline $\mathbf{2 4}$ & $\underline{\text { Cyprus }}$ & 67.8 & -0.1 \\
\hline $\mathbf{2 5}$ & $\underline{\text { Belgium }}$ & 67.5 & -0.3 \\
\hline $\mathbf{2 6}$ & $\underline{\text { Hungary }}$ & 66.7 & 0.9 \\
\hline $\mathbf{2 7}$ & $\underline{\text { Kosovo }}$ & 66.6 & -1.3 \\
\hline 28 & $\underline{\text { Turkey }}$ & 65.4 & 0.2 \\
\hline 29 & $\underline{\text { Slovakia }}$ & 65.3 & -0.4 \\
\hline 30 & $\underline{\text { Spain }}$ & 65.1 & 1.5 \\
\hline 31 & $\underline{\text { Slovenia }}$ & 64.8 & 5.6 \\
\hline 32 & $\underline{\text { Albania }}$ & 64.5 & 0.1 \\
\hline
\end{tabular}

\begin{tabular}{|c|l|c|c|}
\hline Rank & Country & Overall & Change \\
\hline 33 & Montenegro & 64.3 & 2.3 \\
\hline 34 & France & 63.9 & 0.6 \\
\hline 35 & Portugal & 63.4 & 0.8 \\
\hline 36 & ltaly & 62.5 & 0 \\
\hline 37 & Serbia & 62.5 & 3.6 \\
\hline & Bosnia and & 61.4 & 1.2 \\
\hline 38 & Herzegovina & 61 & 1.6 \\
\hline 39 & Croatia & 61 & 0.4 \\
\hline 40 & Moldova & 58.4 & 1.1 \\
\hline 41 & Russia & 58.2 & -0.5 \\
\hline 42 & Belarus & 58.1 & 2.3 \\
\hline 43 & Greece & 57.3 & 2.3 \\
\hline 44 & Ukraine & 51.9 & 3.8 \\
\hline
\end{tabular}

\section{References}

Adam Smith, 1776, "An Inquiry into the Nature and Causes of the Wealth of Nations";

Robert A. Lawson, 2006, "On Testing the Connection between Economic Freedom and Growth";

Joshua C. Hall; Robert A. Lawson, 2014, "Economic freedom of the world: An accounting of the literature";

Angjeli. A, 2007, "Tranzition and economic freedom in Albania";

Heritage Foundation, Economic Freedom Index, 2018, Albania 
Daron Acemoglu; Simon Johnson, James A. Robinson, 2005, "Institutions as a fundamental cause of longrun growth";

Economides G, Egger P, 2009, "The role of institutions in economic outcomes": Editorial introduction, European Journal of Political Economy 9-2009, 277-279;

Daniel L. Bennett Hankamer, Boris Nikolaev Hankamer, Toke S. Aidt, 2018, "Editorial Institutions and wellbeing"; 